\title{
Accuracy of the UAV-Based DEM of Beach-Foredune Topography in Relation to Selected Morphometric Variables, Land Cover, and Multitemporal Sediment Budget
}

\author{
Joanna Rotnicka ${ }^{1}$ (D) Maciej Dłużewski ${ }^{2}$ - Maciej Dąbski ${ }^{2}$ Mirosław Rodzewicz ${ }^{3} \cdot$ Wojciech Włodarski ${ }^{1} \cdot$ Anna Zmarz $^{4}$
}

Received: 17 July 2019 / Revised: 12 January 2020 / Accepted: 23 April 2020 / Published online: 16 May 2020

(C) The Author(s) 2020

\begin{abstract}
Recent developments in unmanned aerial vehicles (UAVs) have resulted in high-resolution digital elevation models (DEMs) of vulnerable coastal environments, including beach-foredune topography. If performed repetitively, they can offer an excellent tool to determine the spatial and temporal changes in the sediment budget, which may be required for proper land management. However, the quality of a UAV, slope parameters, and vegetation significantly influence DEM accuracy. The aim of this study is to compare precise GPS-RTK transects across a section of the South Baltic coast in Poland with those obtained from a DEM based on high-resolution and high-accuracy images obtained by a wind-resistant, high-quality fixed-wing UAV during beyond visual line of sight operation (BVLOS). Different land cover classes, slope inclination, and general curvature, as well as surface roughness, were taken into consideration as possible factors influencing the uncertainty. The study revealed that marram grass greatly affects the accuracy of the UAV-derived model and that the uncertainty of the UAV-derived DEM increases together with increasing slope inclination and, to a lesser degree, with increasing general slope curvature. We showed that sediment budget determinations with the use of a UAV-based DEM are correct only where grass cover is sparse, in our study, up to $20 \%$ of the area.
\end{abstract}

Keywords UAV imaging $\cdot$ DEM accuracy $\cdot$ Beach-foredune topography $\cdot$ Sediment budget

\section{Introduction}

Foredunes are characterized by diversified relief with annual changes ranging between a few centimeters and 1-2 $\mathrm{m}$ (Nolet et al. 2018). High-resolution digital elevation models (DEMs)

Communicated by Nancy L. Jackson

Joanna Rotnicka joanrot@amu.edu.pl

1 Institute of Geology, Faculty of Geographical and Geological Sciences, Adam Mickiewicz University in Poznań, ul. Bogumiła Krygowskiego 12, 61-680 Poznań, Poland

2 Department of Geomorphology, Faculty of Geography and Regional Studies, University of Warsaw, Krakowskie Przedmieście 30, 00-927 Warsaw, Poland

3 Faculty of Power and Aeronautical Engineering, Institute of Aeronautics and Applied Mechanics, Warsaw University of Technology, ul. Nowowiejska 24, 00-665 Warsaw, Poland

4 Department of Geoinformatics, Cartography and Remote Sensing, Faculty of Geography and Regional Studies, University of Warsaw, Krakowskie Przedmieście 30, 00-927 Warsaw, Poland of foredunes repetitively performed offer an excellent opportunity to determine the spatial and temporal distribution of sediment budgets of such dynamic eolian landforms.

Some previous studies have been performed to estimate a foredune sediment budget based on elevation data surveyed with GPS-RTK along transects oriented perpendicular to the coastline and crossing foredune ridges (Vespremeanu-Store and Preoteasa 2007; Delgado-Fernandez 2011), sometimes together with the analysis of aerial photography (Rader et al. 2018). Recently, the sediment budget has also been determined using multitemporal sets of LIDAR-derived DEMs (Keijsers et al. 2014; Darke et al. 2016; Le Mauff et al. 2018) or with the use of aerial images taken by rotary-wing light UAVs. However, such vehicles have limited wind resistivity (Nolet et al. 2018) and can only be used for small surfaces close to the take-off and landing sites under calm weather.

Unmanned aerial vehicles (UAVs) allow the acquisition of high-resolution DEMs of vulnerable coastal environments, including beach-foredune topography. If performed repetitively, they can offer an excellent tool to determine the spatial and temporal changes in the sediment budget, which may be 
required for proper land management. The UAV-based photogrammetry of coastal areas has already proven to be a useful technique for scientific studies as well as for authorities to develop local management strategies (Scarelli et al. 2017). However, there are numerous disturbing factors responsible for DEM inaccuracy, most importantly, the quality of UAVs, slope inclination, and vegetation.

The quality of DEMs is related to the spatial distribution and accuracy of the input elevation data. For example, LIDAR data can achieve an accuracy of $0.2 \mathrm{~m}$ root mean square error (RMSE) horizontally and less than $0.15 \mathrm{~m}$ vertically (Liu 2008). Thus, LIDAR-derived DEMs can display an optimal horizontal spatial resolution of $0.5 \mathrm{~m}$, which is insufficient to detect small-scale geomorphic features (Taroli et al. 2012; Leon et al. 2014; Taroli 2014; Fabbri et al. 2017). In turn, UAVbased DEMs usually have vertical accuracy in the range of approximately 0.05 to $0.1 \mathrm{~m}$ and spatial resolution of approximately $0.1 \mathrm{~m}$ (Mancini et al. 2013; Laporte-Fauret et al. 2019). However, the accuracy of such DEMs is uncertain because the only benchmarks are ground control points installed in selected places. On the other hand, in-field GPS-RTK measurements provide unequivocal results, but they are usually performed along transect lines imposed by survey team protocols.

The spatial resolution and vertical accuracy of the input elevation data and derived DEMs influence the accuracy of detailed geomorphological mapping and the determination of landform sediment budgets (Wheaton et al. 2009; Coveney and Fotheringham 2011; Leon et al. 2014; Le Mauff et al. 2018). Moreover, there is still a poorly known role of the sampling strategy in the input elevation data, the composition of the bare earth surface and the landcover type, topographic complexity, and spatial interpolation methods applied in DEM processing (Hodgson and Bresnahan 2004; Wechsler and Kroll 2006; Bater and Coops 2009). The related DEM uncertainty cannot be simply defined as a single global parameter of dispersion of a difference between predicted and measured ground elevation, i.e., RMSE (Oksanen and Sarjakoski 2006). This is because the uncertainty can be spatially variable depending on land cover type (Hodgson and Bresnahan 2004; Schmid et al. 2011; Zandbergen 2011; Leon et al. 2014) and terrain characteristics such as slope inclination, slope curvature, or surface roughness (Su and Bork 2006; Erdogan 2010; Oksanen and Sarjakoski 2006). Therefore, the proper characterization of the uncertainty, the recognition of its distribution, and spatial correlation structure provide a good basis for realistic DEM uncertainty propagation analysis (Shortridge 2001).

Uncertainty is an inherent feature of any spatial data (Leon et al. 2014), but new technologies allow researchers to maximize the precision of geomorphological measurements. Conventional aerial images or satellite data are usually obtained at a different time than in-field measurements and/or they lack sufficient resolution. The aim of this study is to fill this gap by juxtaposing two measurement approaches: (i) GPS-
RTK transects performed yearly from October 2013 until May 2019 with (ii) transects obtained from detailed DEMs based on high-resolution and high-accuracy images from a fixed-wing UAV platform. We analyze the absolute elevation differences (AED) obtained from GPS-RTK measurements in 2013-2019 and look for environmental factors responsible for the differences, such as land cover classes, slope inclination, general slope curvature, and surface roughness. We propose the following research questions: (1) To what degree do vegetation cover and inclination of a slope influence the precision of foredune and beach sediment budgets obtained from UAVbased images? and (2) In what time scale can we analyze sediment budget under the particular vegetation cover of a foredune and a beach using UAV images?

\section{Study Site}

The study was conducted in Słowiński National Park, on the Łeba Barrier (S Baltic coast) built with a Holocene marine lagoon and eolian deposits (Fig. 1) (Rotnicki 1995; Rotnicki and Borówka 1995). The central part of the barrier is characterized by extensive active transgressive dunes, barchans, barchanoidal ridges, and large-scale parabolic forms (Borówka 1990). The tideless beach (Bobertz et al. 2005) is accompanied by a foredune ridge complex that is unaltered by humans.

The dominant effective winds of the Łeba Barrier blow alongshore and onshore from the SW and $\mathrm{W}$ directions (Rotnicka 2011, 2013a; Rotnicka and Dłużewski 2019). Late autumn and winter are periods with the highest frequency of storms, and the average monthly wind velocities often exceed $5 \mathrm{~ms}^{-1}$. The mean annual precipitation is $611-679 \mathrm{~mm}$, and the relative air humidity is $81-83 \%$ (Rotnicka 2013a). The beach sand remains moist for a significant part of the year.

During the study, the beach had a relatively low gradient and was tens of meters wide (locally up to $150 \mathrm{~m}$ ). Both the foredune complex and the beach were composed of very welland well-sorted fine to medium quartz sand with local zones of pebbles. Surface sand samples averaged $1.95 \mathrm{phi}(260 \mu \mathrm{m})$ in diameter with a sorting value of 0.34 phi (Rotnicka 2013b).

\section{Methods}

\section{UAV Operation}

Aerial images were taken by a PW-ZOOM fixed-wing UAV (Fig. 2), designed, manufactured, and tested at the Warsaw University of Technology in Poland (Goetzendorf-Grabowski and Rodzewicz 2016; Rodzewicz et al. 2017). The photogrammetric flight was performed as a beyond visual line of sight (BVLOS) operation with observers on 23 May 2017 with a starting and landing point located on a beach in Słowiński N.P. 

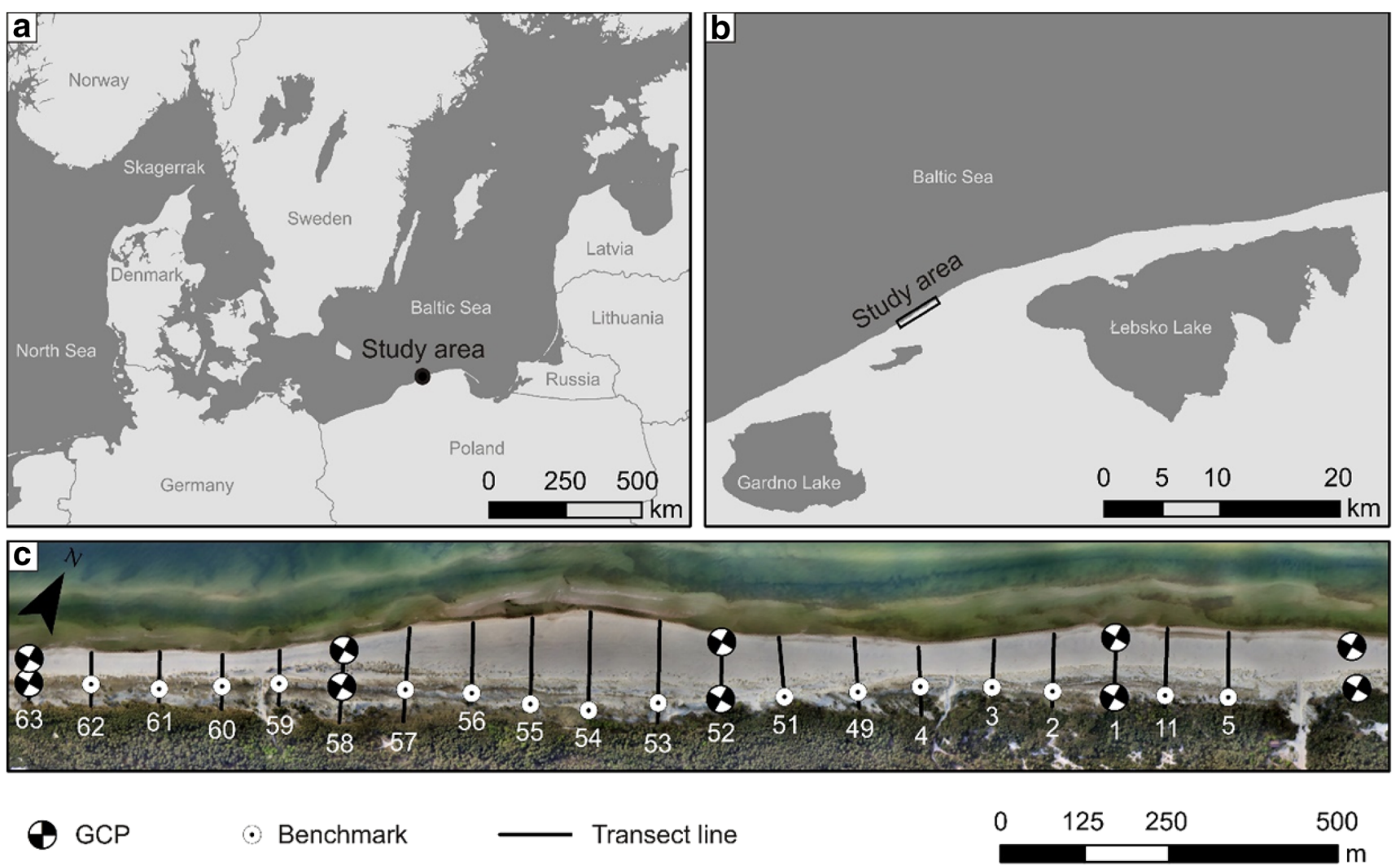

Fig. 1 Location of the study area and GPS-RTK measurement: a study area location at the Baltic Sea, b study area within the Łeba Barrier (note the neighboring coastal lakes), and $\mathbf{c}$ GPS-RTK transects in the study area

The distance between the grid lines was approximately $60 \mathrm{~m}$, which provided $70 \%$ forward and side overlap, the length of the lines was $6500 \mathrm{~m}$, and the flight altitude was $350 \mathrm{~m}$ a.s.l.
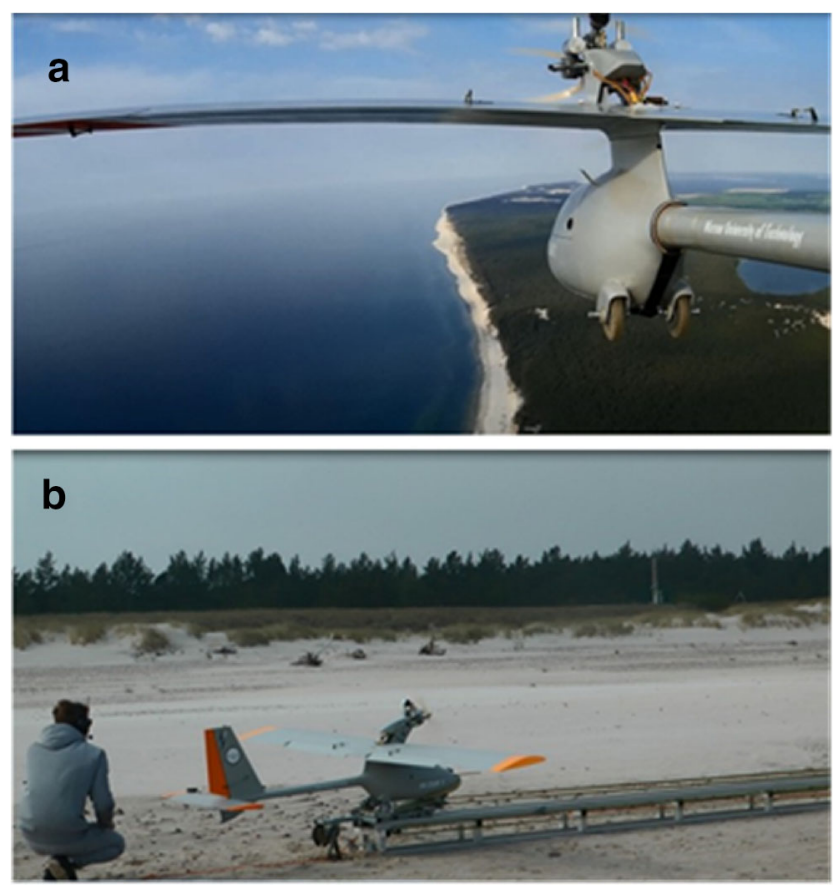

Fig. 2 PW-ZOOM during flight over the Łeba Barrier (a) and starting on a beach (b)
(Table 1, Fig. 3). All images had georeferences $(X, Y, Z)$ registered by the autopilot logger mounted on the UAV. To increase the accuracy of the UAV images, we used 10 ground control points (GCPs) measured with a GPS-RTK.

The UAV operation was performed a day after GPS-RTK measurement under prolonged calm weather conditions; therefore, no morphological changes to the foredunes occurred during the study.

\section{GPS-RTK Transects}

Twenty topographic transects normal to the shoreline orientation, extending from a point landward of the lee slope of the

Table 1 The parameters of the aerial survey to the SPN performed on 23 May 2017 with a of fixed-wing UAV PW-ZOOM

\begin{tabular}{ll}
\hline Number of flights & 1 \\
Total time of flight & $1 \mathrm{~h} 8 \mathrm{~min} 43 \mathrm{~s}$ \\
Camera set & Canon 700D with $35 \mathrm{~mm}$ lens (RGB) \\
Number of images & 1248 (RAW) \\
Distance & $122 \mathrm{~km}$ \\
Flight altitude & $350 \mathrm{~m}$ a.s.l. \\
GSD & $0.04 \mathrm{~m}$ \\
GCP & 10 \\
\hline
\end{tabular}


Fig. 3 Flight path over the beach and the foredune on Łeba Barrier on 23 May 2017; the white rectangle indicates the study site



foredune (usually a benchmark), across the established and incipient parts of the foredune complex, and out to the upper edge of a swash zone were performed in October $(2013,2014$, $2015,2016)$ and May $(2017,2018,2019)$. The length of the profiles ranged from 150 to $250 \mathrm{~m}$ (Fig. 1).

The measurements were taken at the beginning by a TOPCON electronic total station theodolite (TST) and then by using a TOPCON HiPer® Pro real-time kinematic (RTK) differential global positioning system (DGPS) (precision of $0.01-0.02 \mathrm{~m}$ in all dimensions). The average intervals between measurement points ranged between 0.4 and 1.49 within the foredune and between 1.2 and $3.44 \mathrm{~m}$ on the flat beach surface. A set of permanent benchmarks was installed on an established foredune for the base station and for horizontal and vertical correction of the position. Repeated GPS-RTK surveys of a selected beach-foredune profile showed that the error obtained (discrepancy in readings) equaled to $0.01 \mathrm{~m}$, and in $95 \%$ of the readings, it was smaller than $0.034 \mathrm{~m}$.

\section{Land Cover Types}

Three classes of land cover were distinguished (Fig. 4) based on the UAV true-color orthophoto of $0.04 \mathrm{~m}$ spatial resolution: (i) bare beach (no marram grass)—class 1, (ii) dunes with marram grass covering up to $20 \%$ of the surface area-class 2, and (iii) surfaces covered with marram grass of density greater than $20 \%$ - class 3.

Class 2 includes surface with single marram grass shoots and tufts that were partly buried during episodes of intensive sand transport. In fact, they are the topmost part of grass tufts with a height of up to $50 \mathrm{~cm}$ covering the incipient foredune. This class of land cover is also present on established foredunes where marram grass is being slowly replaced by Corynephorus canescens.
Class 3 includes surface covered by large and dense tufts of marram grass usually occurring on periodically inactive fragments of incipient foredunes and established foredunes. It also may be present on the upper part of the beach where single marram grass tufts are responsible for formation of shadow dunes. The height of the tufts in this land cover class is 70 $90 \mathrm{~cm}$.

Marram grass shoots were counted and measured in randomly selected $1 \mathrm{~m}^{2}$ plots. The height and width/diameter of the tufts were measured (Musick et al. 1996). Based on these measurements, the percentage of area coverage by the grass was calculated. In class 2 , the percentage of vegetated surface was usually less than $10 \%$ (sporadically a dozen or so percent). In class 3 , the grass coverage was usually well above $20 \%$, depending on the dimension and distribution of grass tufts.

\section{UAV Data Processing}

The UAV images were obtained in RAW format during the flight and converted to JPEG format in the Digital Photo Professional version 3.13.0.1 (Canon Inc.) software. The images were then processed into an orthophoto with a resolution of $0.04 \mathrm{~m}$ and a dense 3D point cloud in the original WGS84 coordinate system. The Agisoft Photoscan Professional software Version 1.3.2 build 4205, 64 bit (Agisoft LLC.) and the structure from motion (SfM) algorithm were used to create these data. Agisoft software estimates internal and external camera orientation parameters during photo alignment. This estimation is performed using only image data, and therefore, there may be some errors in the final estimates. The accuracy of the final estimates depends on many factors, such as overlap between the neighboring photos, as well as on the shape of the object surface. These errors can lead to nonlinear deformations of the final model. 

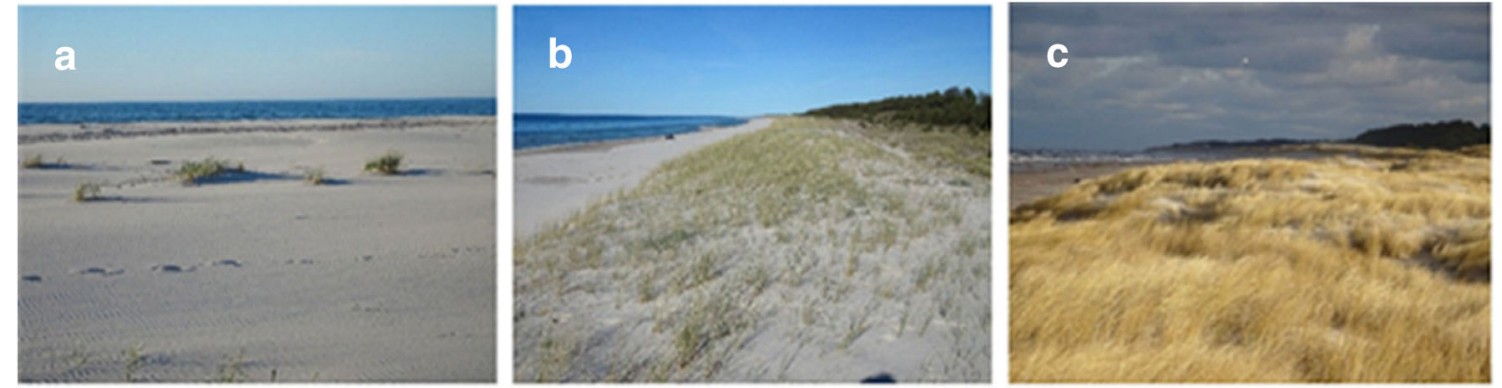

Fig. 4 Land cover classes: A without marram grass (class 1), b marram grass covering up to $20 \%$ of the dune area (class 2), and $\mathbf{c}$ marram grass covering over $20 \%$ of the dune area (class 3 )

\section{Digital Terrain Modeling}

The 3D point cloud was transformed to the LAS data format and then reprojected to a national metric coordinate system. Then, we performed digital terrain modeling that included the spatial analysis of the point cloud data, the processing of the digital elevation model (DEM), the computation of DEMderived terrain variables, and DEM uncertainty analysis. All computations and spatial analyses were performed using ArcGIS 10.5 software (Esri 2018), SAGA GIS open source software (Conrad et al. 2015), and Tableau 10.5 data mining software (Tableau Software, Seattle, WA, USA). The point cloud data were dynamically triangulated to prepare a raw multiresolution DEM. This modeling method, based on the TIN (triangulated irregular network) data structure, was chosen taking into account the total number of elevation points (approximately 15 million), and the irregular but dense spatial distribution of these points (mean distance between neighboring points is $0.11 \mathrm{~m}$ and standard deviation is $0.03 \mathrm{~m}$ ). According to earlier studies (Bater and Coops 2009; Hengl and Evans 2009), the approach used allowed us to obtain a more accurate DEM displaying discrete changes in topography, thus minimizing the potential uncertainty of the modeled elevation due to the data interpolation process.

The computation of DEM-derived terrain variables, including slope inclination, general slope curvature, and surface roughness, was based on a high-resolution gridded DEM. The optimal spatial resolution of $0.2 \mathrm{~m}$ was assumed for this DEM as a compromise between its value of $0.05 \mathrm{~m}$ determined by the point pattern analysis method (Hengl 2006) and the need to upscale the resolution to reduce the smallscale variation and obtain a more general pattern of the terrain variables. It is obvious that the small-scale variation should be free from pure artifacts related to spikes and pits having a size of a few grid cells on a high-resolution DEM, directly derived from UAV-based photogrammetric processing (Nelson et al. 2009). A natural neighbor gridding method was chosen here to avoid the oversmoothing effect given by other gridding methods, such as spline or kriging (Taroli et al. 2012). However, the resulting gridded DEM was smoothed using a low-pass filter in a $3 \times 3$ moving window $(0.6 \times 0.6 \mathrm{~m})$ to obtain the final DEM free from remaining local outliers and appropriate for the computation of terrain variables (Kienzle 2004; Hengl 2006).

The slope inclination (in ${ }^{\circ}$ ) and general slope curvature (defined as the rate of local change in slope inclination and aspect to determine the degree of surface concavity and convexity) were calculated using a $3 \times 3$ grid-cell moving window following the second-order polynomial method of Zeverbergen and Thorne (1987). The surface roughness was determined based on the computation of the vector roughness measure (VRM) (Sappington et al. 2007). The VRM is an indicator of surface heterogeneity according to local changes in slope inclination and aspect, similar to the general slope curvature. Nevertheless, this indicator, calculated using operators with Gaussian weighting functions related to a moving window with a radius of 10 grid cells $(2 \mathrm{~m})$, allowed us to determine a smoothed and artifact-free pattern of surface roughness.

\section{DEM Uncertainty Analysis}

We analyzed the uncertainty of the UAV-based DEM in terms of differences between modeled elevations (DEM-derived) and elevations measured with GPS-RTK in each of the 20 transects performed at the same time as the UAV flight. We also compared the obtained uncertainty with the AED derived from GPS-RTK transects performed annually from 2013 to 2019. Different land cover classes, slope inclinations, general slope curvatures, and surface roughness values were taken into consideration as possible factors influencing the uncertainty. Moreover, the spatial variability of this uncertainty was geostatistically modeled (Webster and Oliver 2007). For this purpose, empirical semivariograms were estimated for fixed distance lags of $0.9 \mathrm{~m}$ length (according to the same mean distance between neighboring points obtained from GPSRTK measurements within the foredunes). The estimations were made for all uncertainty data and their subsets defined on the basis of land cover. The spherical models with nugget effects were fitted to all estimated semivariograms. Based on these models, we were able to recognize the degree to which the discrepancies between modeled and measured elevations 
are spatially autocorrelated (Oksanen and Sarjakoski 2006; Leon et al. 2014).

The differences in elevation between annually measured GPS-RTK transects and the transects obtained from the DEMs based on UAV images were negative or positive (Fig. $4 \mathrm{a}$ and b). However, we were interested in finding the environmental factors responsible for the differences in general; therefore, we analyzed the AED in which we disregarded the direction of the differences.

To support the patterns observed on the diagrams, we performed Kruskal-Wallis statistical tests and post hoc tests in Statistica 13.3, assuming the significance level $\alpha=0.05$.

\section{Results}

The elevations of the UAV-derived cloud points determined for the beach and the foredune range from -0.2 to $13.71 \mathrm{~m}$ a.s.l. The horizontal and vertical accuracies of these data, checked using GPS-RTK measurements at the GCP validation, are shown in Table 2. The uncertainty of DEM processed from the point cloud data is spatially distributed regarding land cover classes and three terrain variables (slope inclination, general slope curvature, and surface roughness). The absence of collinearity between these variables was confirmed using the Pearson correlation matrix. The correlation coefficients between variables are up to 0.13 , suggesting a low level of redundancy.

There is a gradual increase in the AED between land cover class 1 (beach with no grass), a foredune with low grass density (land cover class 2), and a foredune with dense high grass (land cover class 3), with median values for AED being $0.06 \mathrm{~m}, 0.09 \mathrm{~m}$, and $0.16 \mathrm{~m}$, respectively (Fig. $5 \mathrm{c}$ ). This general tendency is well shown by transect K60 (Figs. 1 and $5 \mathrm{~d}$ and e) running through the three land cover classes.

The AED attains values up to approximately $0.4 \mathrm{~m}$ but most frequently falls below $0.05 \mathrm{~m}$ (Figs. 6a, 7, 8, and 9a).

Table 2 Horizontal and vertical accuracy between DEM and GPS-RTK data calculated at the GCP validation

\begin{tabular}{llr}
\hline GCP & Horizontal accuracy $(\mathrm{m})$ & Vertical accuracy $(\mathrm{m})$ \\
\hline 63-beach & 0.040 & 0.027 \\
63-benchmark & 0.002 & -0.051 \\
58-beach & 0.083 & -0.008 \\
58-benchmark & 0.046 & -0.002 \\
52-beach & 0.119 & -0.010 \\
52-benchmark & 0.046 & -0.021 \\
1-beach & 0.074 & 0.042 \\
1-benchmark & 0.049 & -0.026 \\
7-beach & 0.048 & 0.004 \\
7-benchmark & 0.024 & 0.017 \\
RMSE & 0.061 & 0.074 \\
\hline
\end{tabular}

For all land cover classes combined, there is a clear tendency for a gradual increase in AED with increasing slope inclination (Fig. 6b). The AED on slopes inclined less than $10^{\circ}$ are statistically significantly different than those on steeper slopes (Appendix). The general slope curvature also exhibits some interrelationship with AED because the slopes of curvature between -0.05 and +0.15 stand out as having significantly different AED (Fig. 6c, Appendix).

The same analyses performed only for the area with no grass (land cover 1) show that no terrain variables control the AED, as can be read from the AED distribution diagrams (Fig. 7) and statistical tests (Appendix).

A similar tendency for all land cover classes combined (Fig. 6 ) is observed for land cover class 2 (marram grass covering up to $20 \%$ of the area) (Fig. 8). However, the tendency is less clear, and statistically significant differences are obtained only for AED populations on slope inclinations exceeding $20^{\circ}$ (Appendix). The situation with general slope curvature is very similar to that for all land cover classes combined, as statistically significant differences are obtained for AED populations on the slopes of curvature between -0.05 and +0.15 (Appendix).

If the analyses are limited to land cover 3 (marram grass over $20 \%$ of the area), then a gradual increase in AED can be observed toward greater slope inclination (Fig. 9); however, there are no statistically significant differences (Appendix). AED seemed to decrease as the general slope curvature increased, but again, this pattern was not supported by statistical tests (Appendix).

The influence of slope inclination on AED is lowest in places free of vegetation (land cover class 1) and greatest in places with relatively dense marram grass (land cover class 3 ) where maximum AED values are $0.4 \mathrm{~m}$ (Fig. 10). In general, thick grass and high slope inclination result in significant errors in UAV-based DEMs.

The autocorrelation structure of the DEM uncertainty determined on semivariograms shows the different spatial dynamics of the discrepancy between the predicted and measured elevation data (Fig. 11). In the case of all analyzed data, the nugget effect of $0.0049 \mathrm{~m}^{2}$ at a distance less than the sampling interval shows a pure random variation in the DEM uncertainty of approximately $0.09 \mathrm{~m}$. The following spatial structure described by the spherical model allowed us to determine the range of the autocorrelation of $11.5 \mathrm{~m}$ with a partial sill of $0.0073 \mathrm{~m}^{2}$, indicating the degree of spatial variability or trend in the DEM uncertainty up to approximately $0.12 \mathrm{~m}$ depending on the distance between the analyzed data. There are noteworthy differences between the semivariograms estimated for the DEM uncertainty partitioned into four subsets with respect to the land cover classes (Fig. 4) and in the case of class 1 regarding the morphology of the beach (flat beach, beach with small shadow dunes). The spatial autocorrelation structures determined here vary not only in the range of autocorrelation (from $5.52 \mathrm{~m}$ for the beach with shadow dunes to $15 \mathrm{~m}$ for the flat beach) but also first in the nugget/sill 

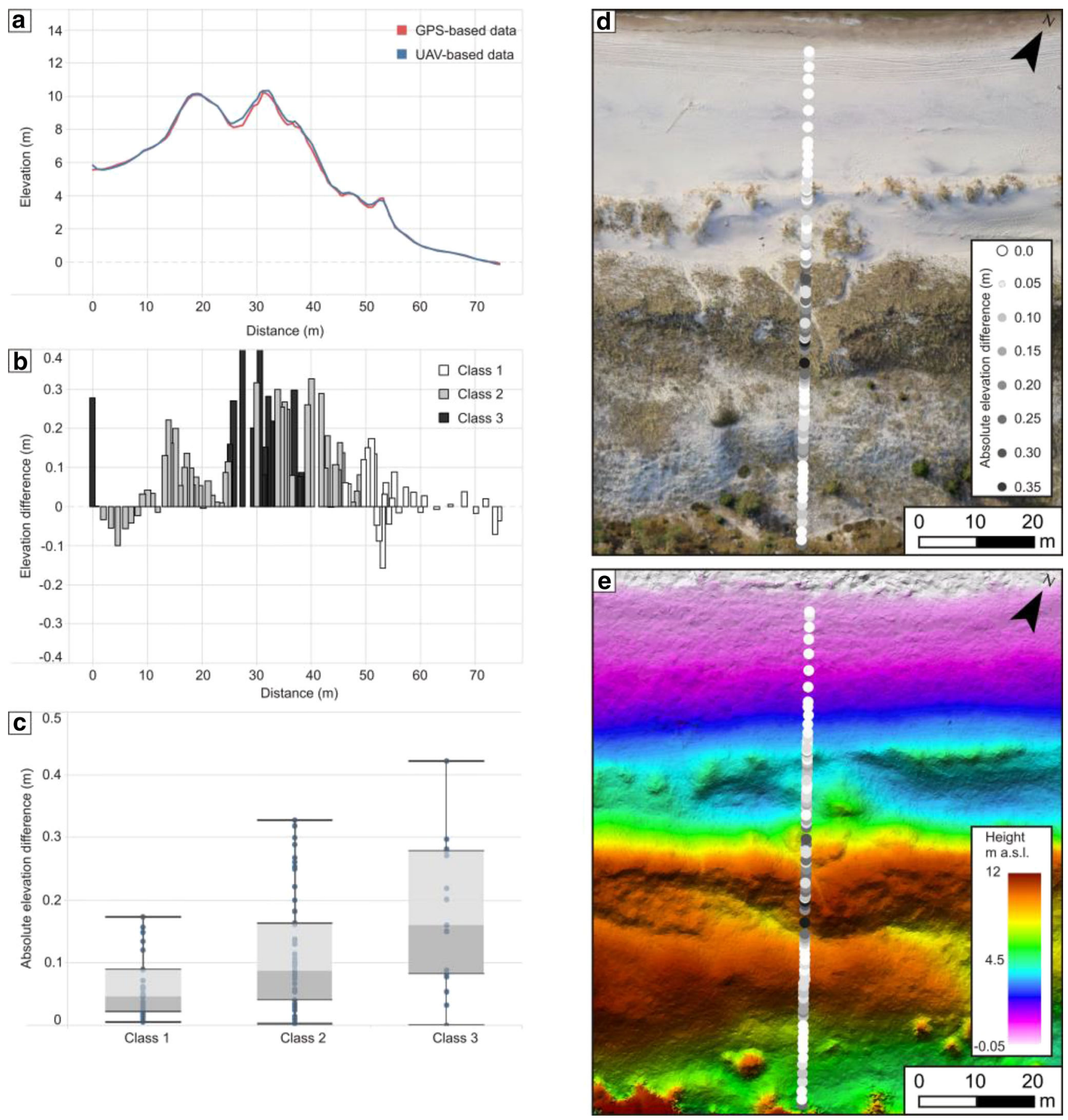

Fig. 5 Transect K60: a elevation profiles based on GPS-RTK measurements and UAV-derived DEM, b elevation differences along the elevation profile (note different cover classes), $\mathbf{c}$ elevation differences in the three land cover classes ( 1 - no grass, 2 - up to $20 \%$ grass cover, 3 - over

$20 \%$ grass cover), $\mathbf{d}$ vegetation and relief in the area of the profile, and $\mathbf{e}$ elevation change between the GPS-RTK measurements and UAVderived DEM. Boxplots represent the interquartile range with the median and whiskers corresponding to 1.5 times the interquartile range

ratio, which indicates the strength of spatial dependency related to the pure random variation in the DEM uncertainty. The ratios observed for the flat beach, dunes with marram grass, and beach with shadow dunes $(0.48,0.42$, and 0.52 , respectively) show a high degree of local random variation in the uncertainty and their low spatial dependency. In turn, this ratio

of 0.12 related to the DEM uncertainty of the area of dense marram grass may be indicative of a low degree of small-scale random variation and high spatial autocorrelation.

The comparison of the AED between GPS-RTK topographic profiles measured in 2015, 2016, and 2019 and a topographic profile that took into account the uncertainty of 

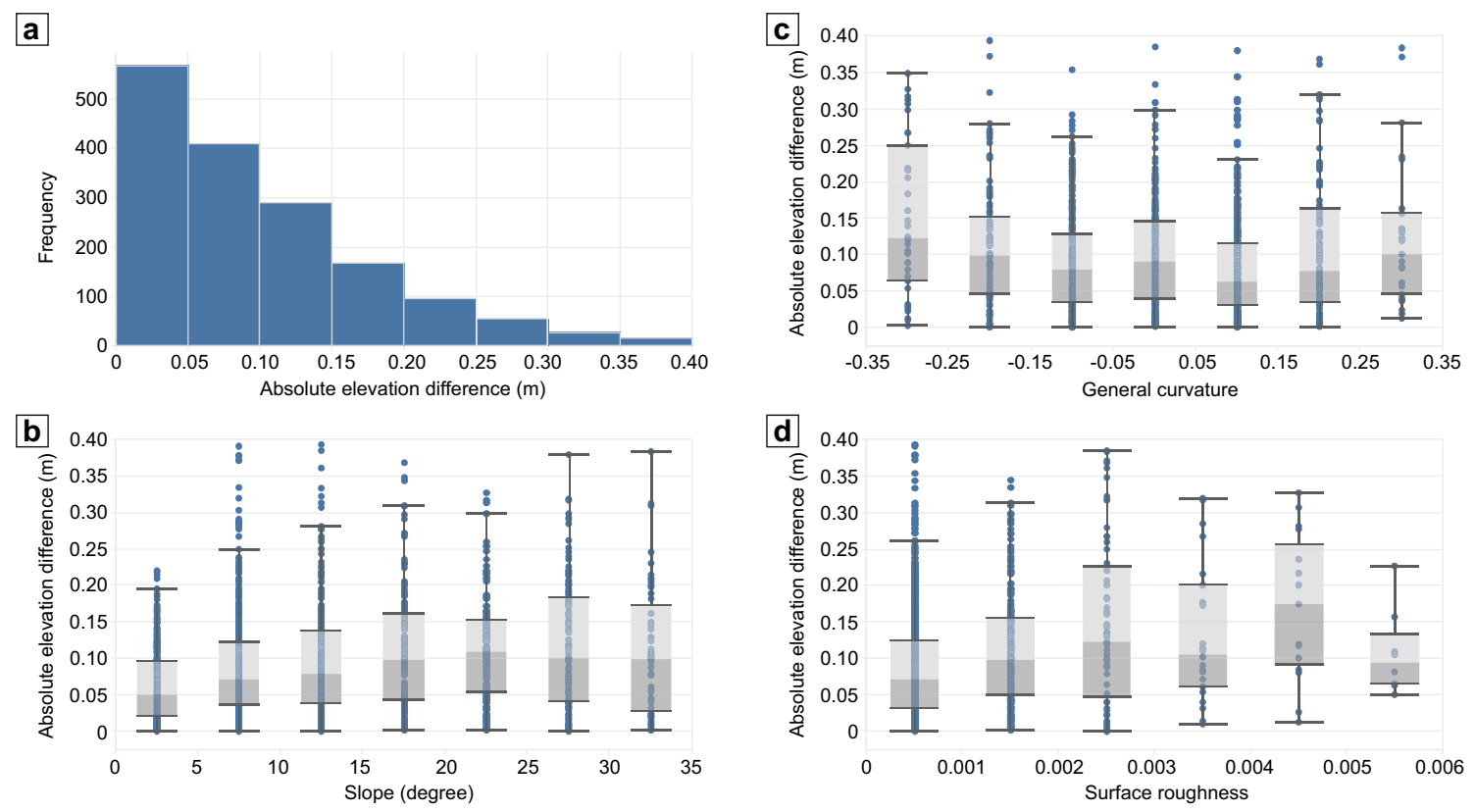

Fig. 6 Differences in altitude between GPS-RTK measurements and UAV-derived DEM for all vegetation classes (1,2, and 3) combined: a frequency of AED, b AED in relation to slope inclination, $\mathbf{c}$ AED in

measurements obtained from the UAV-based DEM in 2017 allowed us to conclude that a proper determination of a sediment budget based on UAV images depends on land cover classes. In the transect in which classes 1 and 2 predominate (Fig. $12 \mathrm{a}$ and $\mathrm{b}$ ), the differences in altitude are much greater relation to general slope curvature, and $\mathbf{d}$ AED in relation to surface roughness; boxplots represent the interquartile range with the median and whiskers corresponding to 1.5 times the interquartile range

than the uncertainty of the measurements. On the other hand, where land cover 3 dominates, these differences are comparable to the uncertainty of the measurements.

Elevation differences for vegetation-free areas (land cover class 1) obtained for particular GPS-RTK
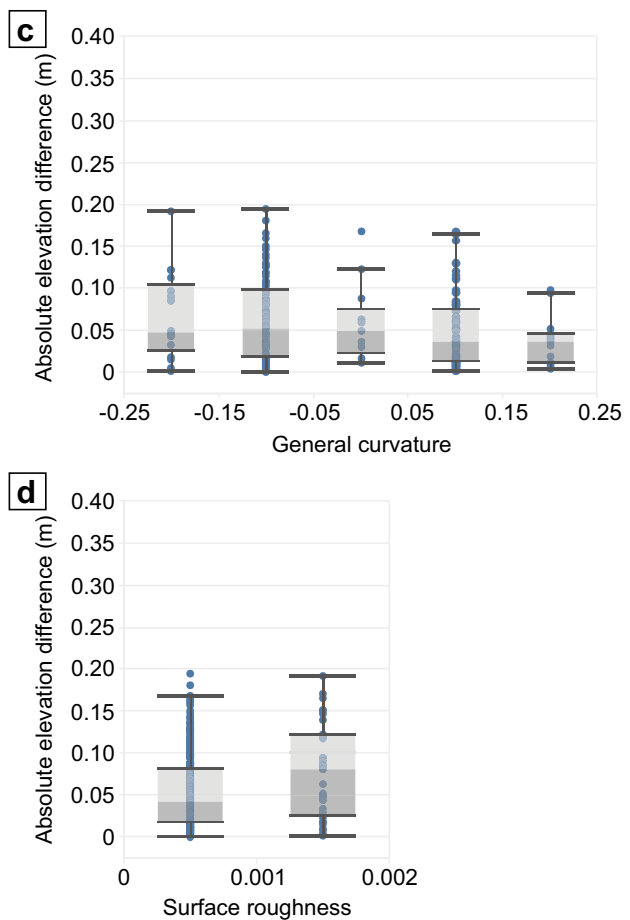

relation to general slope curvature, and $\mathbf{d}$ AED in relation to surface roughness; boxplots represent the interquartile range with the median and whiskers corresponding to 1.5 times the interquartile range 

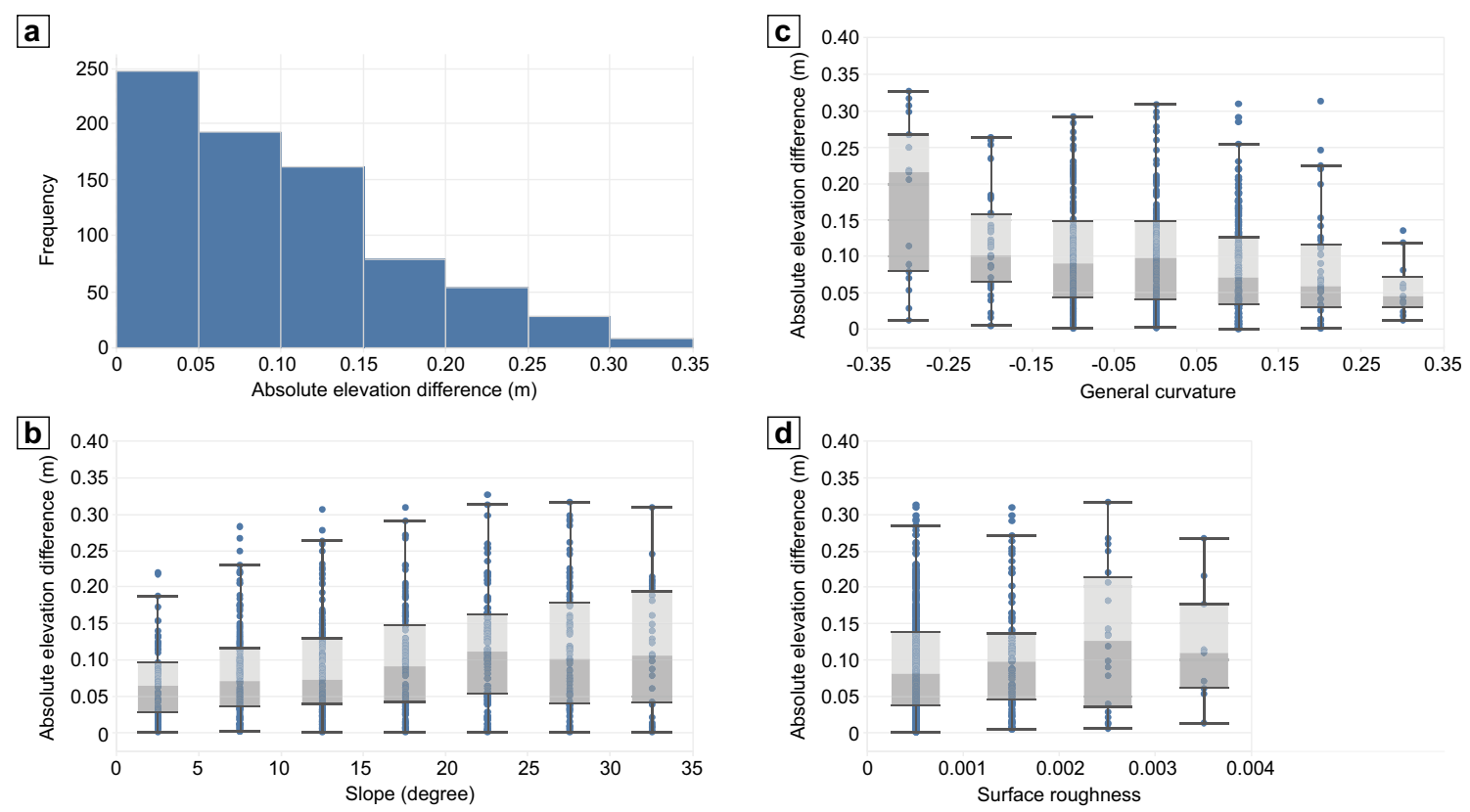

Fig. 8 Differences in altitude between GPS-RTK measurements and UAV-derived DEM for land cover class 2 (marram grass cover up to $20 \%$ of the dune area): a frequency of AED, b AED in relation to slope

inclination, $\mathbf{c}$ AED in relation to general slope curvature, and $\mathbf{d}$ AED in relation to surface roughness; boxplots represent the interquartile range with the median and whiskers corresponding to 1.5 times the interquartile range

measurements performed annually (median for: 1-year measurement period $-0.038 \mathrm{~m}$, for a 4 -year period$0.056 \mathrm{~m}$ ) are much larger than the uncertainty of measurement determined for a UAV-based DEM (median $0.006 \mathrm{~m}$ ) (Fig. 13a). This makes it possible to determine the sediment budget with the use of the UAV-based DEM, even on

a
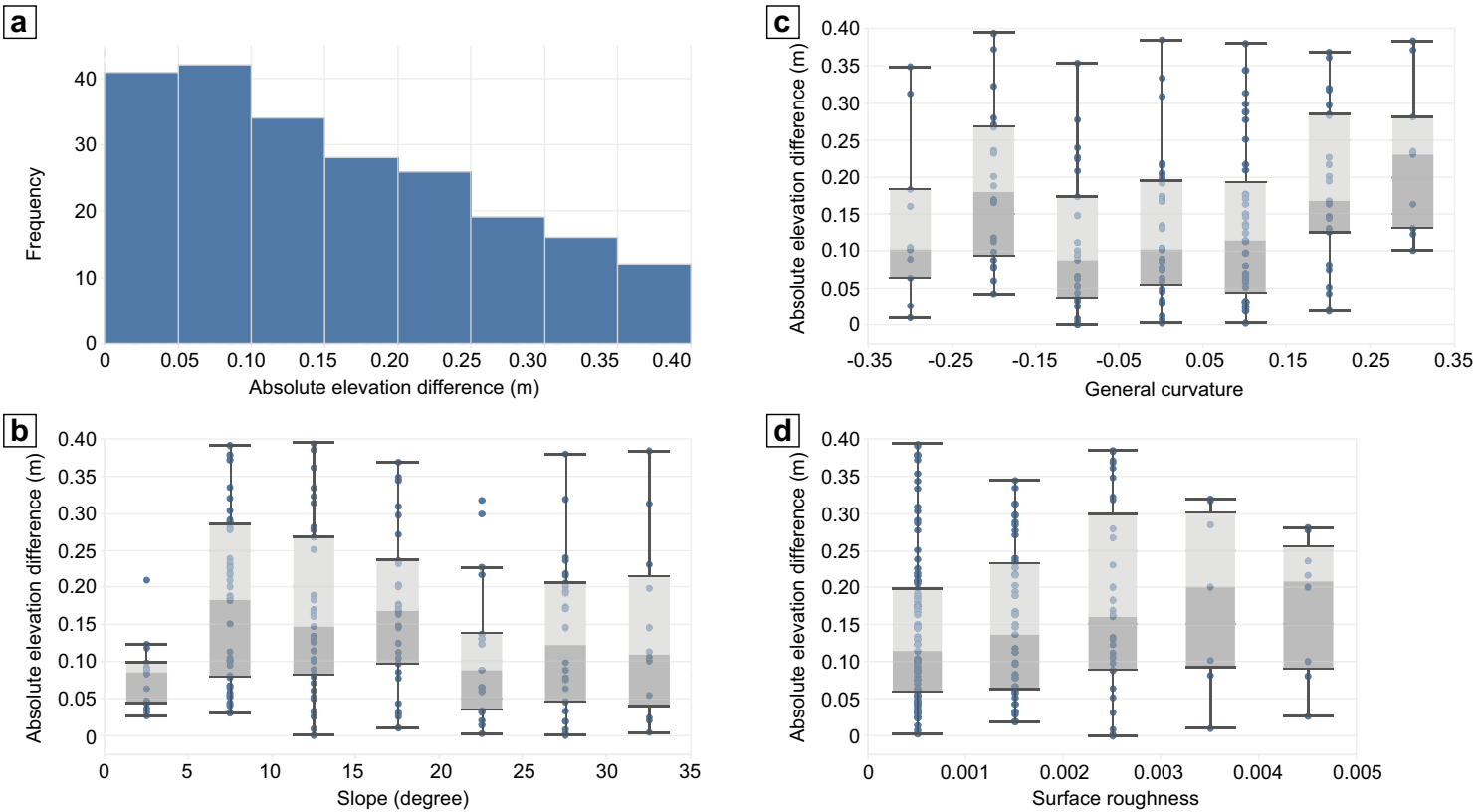

Fig. 9 Differences in altitude between GPS-RTK measurements and UAV-derived DEM for land cover class 3 (marram grass covering over $20 \%$ of the dune area): a frequency of AED, $\mathbf{b}$ AED in relation to slope inclination, $\mathbf{c}$ AED in relation to general slope curvature, and $\mathbf{d}$ AED in

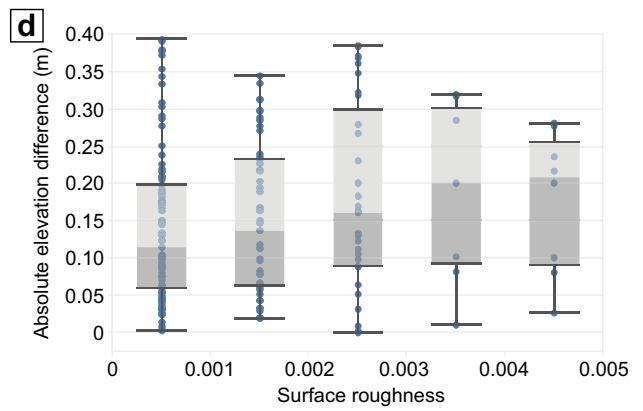

relation to surface roughness; boxplots represent the interquartile range with the median and whiskers corresponding to 1.5 times the interquartile range 
Fig. 10 Change in absolute elevation differences (AED) in relation to slope inclination and different land cover classes; the diagram shows minima, maxima, medians, and lower and upper quartiles

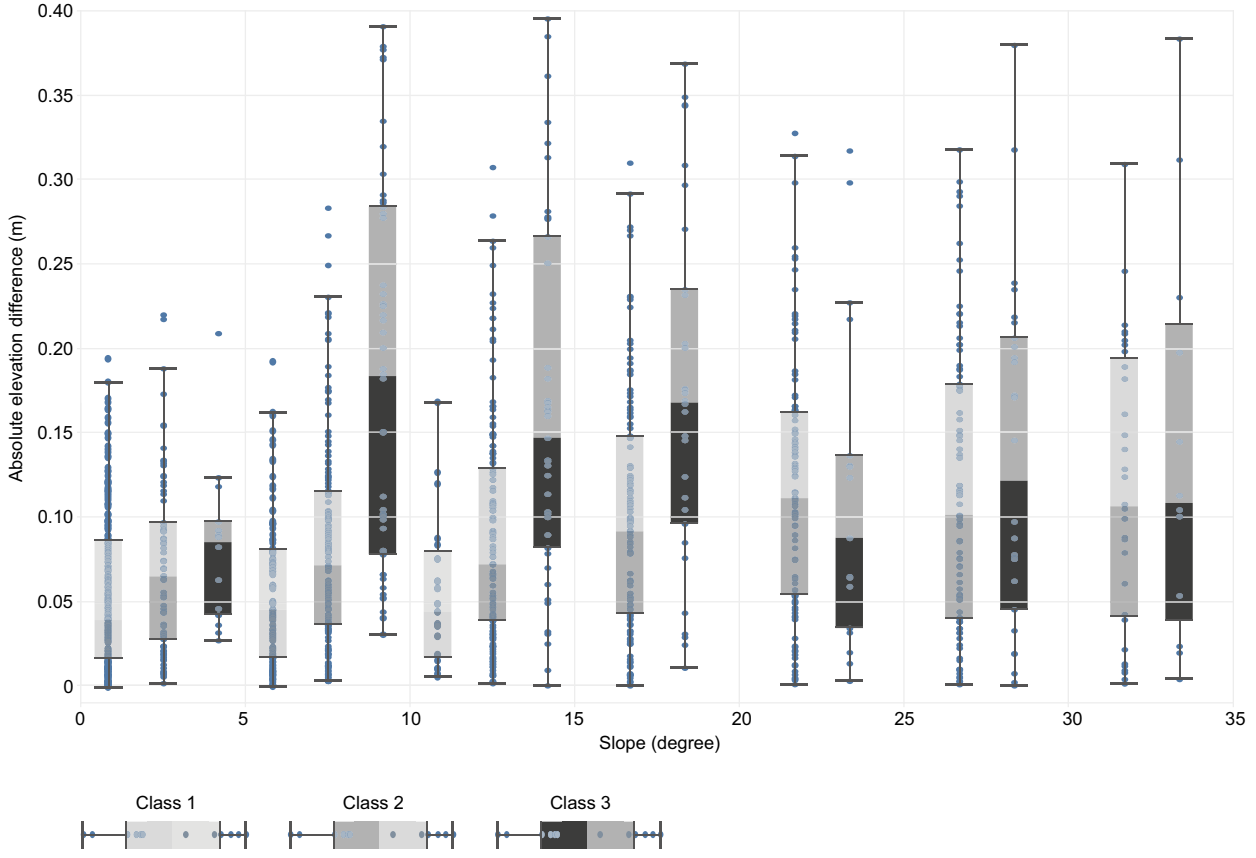

In the case of land cover class 2 (Fig. 13b), where the sediment budget is exclusively associated with eolian processes (Fig. 13b), the UAV-based DEM uncertainty is slightly higher than that in the case of land cover 1 . The AED between particular GPS-RTK profiles varies greatly (up to $4 \mathrm{~m}$ in a year) and, on average, is much larger (median for: 1-year period- $0.023 \mathrm{~m}$, for a 4-year period- $0.058 \mathrm{~m}$ ) than the UAV-based DEM uncertainty (median $0.009 \mathrm{~m}$ ). By using a UAV-based DEM on land cover class 2, we could also correctly determine the sediment budget even on a 1-year time scale.

The use of the UAV-based DEM in the determination of a sediment budget of land cover class 3 appears to be inappropriate (Fig. 13c). This is due to the large UAV-based DEM uncertainty (median $0.011 \mathrm{~m}$ ), significant stabilization of the substrate by vegetation, and therefore relatively small values of the sediment budget (median for: 1-year measurement period $-0.007 \mathrm{~m}$, for a 4-year period- $0.011 \mathrm{~m}$ ).



Fig. 11 Empirical semivariograms of the UAV-based DEM uncertainty (point symbols) and fitted spherical models with nugget effects (lines) 

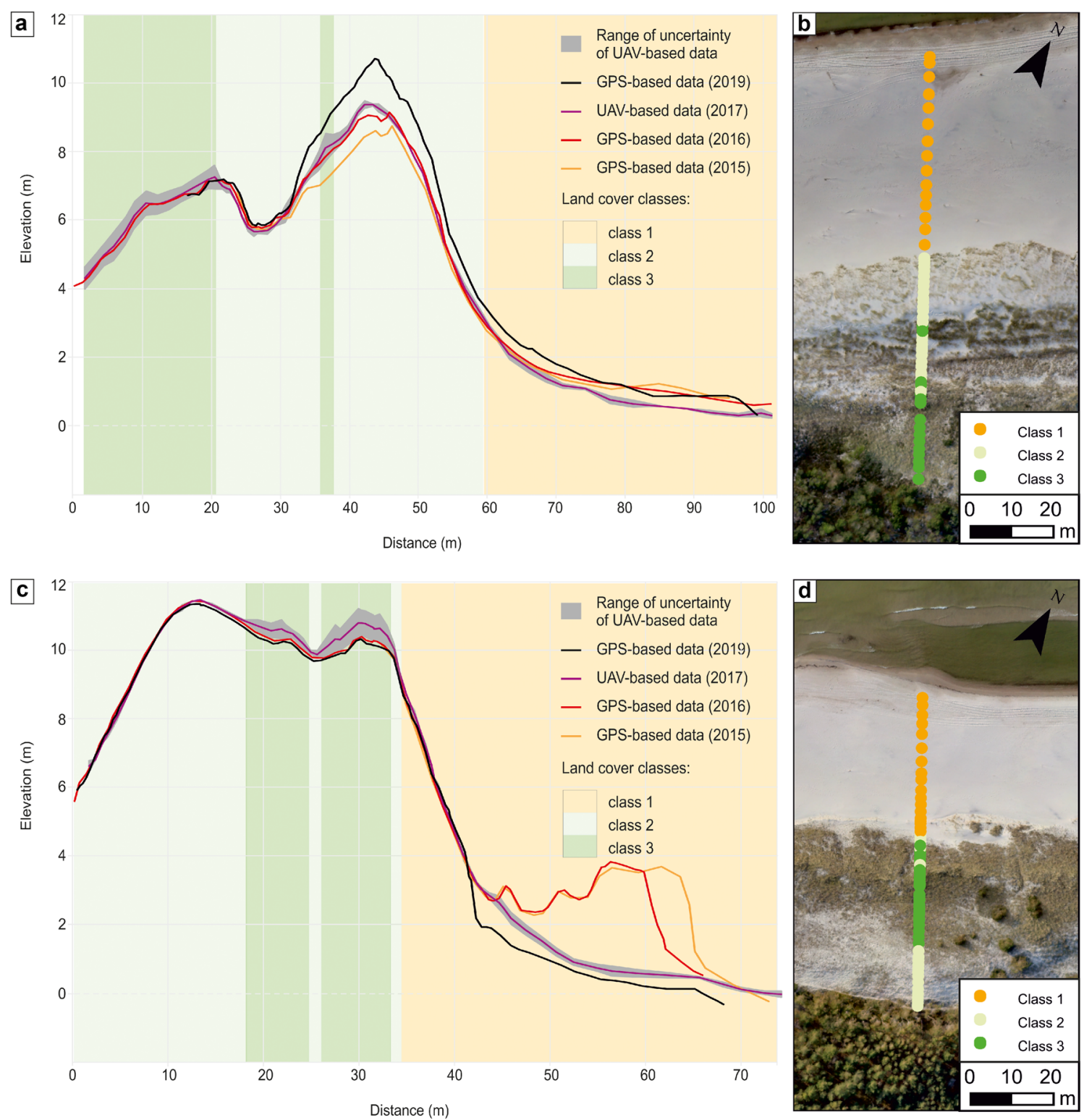

Fig. 12 Examples of morphological cross-sections displaying multitemporal differences between topography and the range of uncertainty of the UAV-based elevation data. a, c Morphological cross-

sections along transect lines 2 and 62, respectively (for transect location, please refer to Fig. 1c). b, d Vegetation and relief along respective transect lines

\section{Discussion}

\section{Use of UAV Platforms}

The development of UAV platforms contributed to the time reduction of data acquisition and maintaining high data quality with reduced costs. The availability of UAVs for various geomorphological studies is very broad. In the last decade, UAVs have been applied in studies of landslides (Niethammer et al. 2012), erosion gullies (d'Oleire-Oltmanns et al. 2012; Grellier et al. 2012), debris flows and alluvial fans (de Haas et al. 2014), river channels (Flener et al. 2012), glacial landforms (Whitehead et al. 2013; Chandler et al. 2016), periglacial landforms (Dabski et al. 2017), volcanic landforms (Zmarz et al. 2018), karstic landscapes (Silva et al. 2017), coastal dunes (Laporte-Fauret et al. 2019), hot arid deserts (Angell 2018), and structural geomorphology (Kasprzak et al. 2017). In comparison to manned aircraft, UAVs require a lower level of engagement of qualified personnel and advanced ground infrastructure and lower costs. Moreover, its use is safe if the conditions of use of the airspace are met. Most UAV users perform flights within the visual line of sight of the operator (VLOS). Flights BVLOS require additional permits as well as proper and safe implementation of the mission. Rare examples of BVLOS operations in geomorphological studies are provided by Dąbski et al. (2017), Zmarz et al. (2018), and in this study. 
Fig. 13 Boxplots for the three land cover classes (a class 1 - no grass, b class 2-up to $20 \%$ grass cover, c class 3 - over $20 \%$ grass cover) showing changes in the AED (in meters) in relation to the uncertainty of the UAV-based elevation data and temporal scales of the sediment budget. Boxplots represent the interquartile range with the median and whiskers corresponding to 1.5 times the interquartile range
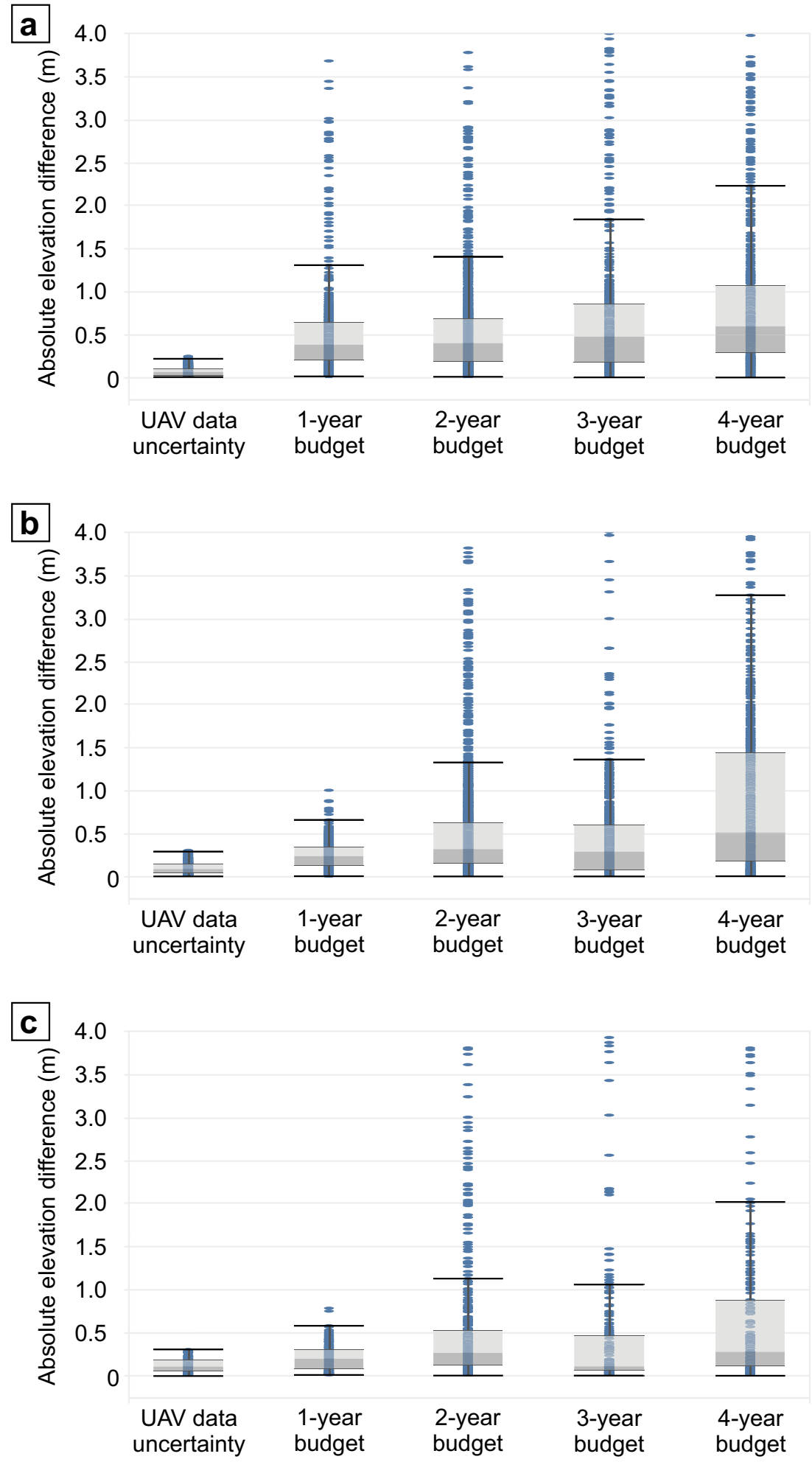

Moreover, the used PW-ZOOM fixed-wing aircraft is much more wind tolerable, up to $23 \mathrm{~ms}^{-1}$ (Zmarz et al. 2018), in comparison with that of rotary UAVs (LaporteFauret et al. 2019), which can operate safely when the wind is lower than $7 \mathrm{~ms}^{-1}$, as in the case of popular light multirotor UAVs (DJI 2016). This makes PW-ZOOM a much better tool for photogrammetric flights in demanding environments such as coastal or polar environments where sudden wind gusts are frequent (Dąbski et al. 2017; Zmarz et al. 2018). 


\section{UAV-Based Relief Modeling}

Relief modeling based on UAV imagery greatly improves the calculations of the sediment budget of beach-foredune systems, but further improvements should be made through the use of similar monitoring systems (Delgado-Fernandez 2011). This should include frequent survey intervals that allow for a spatial-temporal (4D) picture of the coastal area (Darke et al. 2016). UAV platforms are excellent tools for facilitating quick and timely data acquisition if detailed DEMs are of sufficient accuracy.

The sediment budget calculation of eolian landforms is greatly affected by natural vegetation cover (e.g., marram grass) and any human alternation of land cover (Darke et al. 2016). It is therefore of great importance to take into account the influence of vegetation on UAV-based DEMs. LaporteFauret et al. (2019) assessed the influence of marram grass on elevation measurement based on such DEMs, but they did not undertake an in-depth statistical approach. Our study filled this gap by concentrating on different land cover classes (marram grass densities) and slope inclinations as factors controlling elevation measurement errors.

\section{DEM Uncertainty}

The relationship between the spatial autocorrelation structure of DEM uncertainty and topography has been reported at the landscape scale by Oksanen and Sarjakoski (2006). If the long ranges and low sills are typical for the flattest topography, then short ranges and high sills predominate where the terrain is more rugged. In general, our study results support this relationship, particularly with respect to DEM uncertainty analyzed for flat beaches, beaches with shadow dunes, and foredunes covered by dense marram grass. The high sill in the last case can be considered as the effect of small-scale composite topography masked by dense and relatively high marram grass. It is noteworthy that the maximum positive differences between DEMderived elevation data and GPS-RTK measurements were usually observed in this land cover class. Moreover, the low nugget/sill ratio and thus the low degree of small-scale random variation and the high spatial autocorrelation of DEM uncertainty determined here appear to be a consequence of two factors. First, the transition between the area of dense marram grass and other land cover classes is usually not sharp but gradual. For example, the transition from class 3 to class 2 is manifested not only in gradual changes in the density and height of grass cover but also in the tendency to diminish the patches of dense tufts of marram grass. Second, in some cases, the patches of dense marram grass develop on the southern slopes of the foredunes in shadows of small-scale overlapping shadow structures. These two factors probably contributed to the gradual elevation changes in the DEM across the border of the area of dense marram grass despite the different spatial autocorrelation structures of DEM uncertainty in comparison to other land cover classes. Thus, the exclusion of areas densely covered by marram grass from the UAV-based DEMs for the detailed study of geomorphology and the dynamics of beach and eolian processes seems impossible without the precise detection of land cover classes using the image analysis of the UAV-based data in visible and near infrared bands.

The confirmation in the current study that the DEM uncertainty in different terrain types may have varying spatial autocorrelation structures (Goodchild 1995; Oksanen and Sarjakoski 2006) gives the opportunity to solve the optimization problem of spacing between nearest-neighbor RTK-GPS survey points required for DEM uncertainty analysis. According to earlier studies on the optimization of remote sensing mission criteria, including UAV missions, in terms of flight elevation and then the upscaling of the resulting DEM (Rahman et al. 2003; Wang et al. 2019), the nearest-neighbor RTK-GPS survey points can be located at distances up to one-half of the width of the range modeled from the experimental semivariogram. The detailed data collected along regularly spaced transects oriented perpendicular to the coastline and crossing foredune ridges show that the range width and thus the maximum distance of the spatial dependence of the DEM uncertainty are significantly different between the three land cover classes, i.e., flat beach, beach with shadow dunes, and area of dense marram grass preset on incipient or established foredunes. It gives the maximum permissible spacing between the nearest RTK-GPS survey points of up to $7.5 \mathrm{~m}, 2.76 \mathrm{~m}$, and $5.8 \mathrm{~m}$, respectively.

Laporte-Fauret et al. (2019) found a locally strong elevation underestimation of a UAV-based DEM (derived from the SfM algorithm) on the dry beach, which was caused by the locally smooth and featureless sand surface. During our UAV operation, the beach sand was relatively dry, but the accuracy of the DEM was still better than that on uneven foredune surfaces. This calls for further studies aimed at estimating the influence of ground moisture on the accuracy of SfM models.

\section{Conclusions}

In light of global climate change and sea level rise, foredunes play a particularly important role in coastal defense against storm surges. Therefore, proper land management policies should be introduced, and this is difficult to achieve without the accurate modeling of land elevation adjusted for a particular land use type.

We showed that dense marram grass significantly lowers the accuracy of the UAV-derived model and that the greatest absolute elevation differences between UAV-derived DEMs and GPS-RTK measurements are obtained for slope overgrowth by high grass. For all land cover types combined, there 
are the clear tendencies of a gradual increase in absolute elevation differences (the uncertainty of UAV-derived DEMs) together with increasing slope inclination and, to a lesser degree, with increasing general slope curvature. Our results allow us to infer that the sediment budget determinations with the use of a UAV-based DEM are correct only where grass cover is sparse, in our study, up to $20 \%$ of the area.

In spite of obtaining the DEM generated based on the data from the good-quality, wind-resistant fixed-wing UAV, the precise determination of the sediment budget will not always be possible, especially in the areas of foredunes where the sediment mass balance turnover is sometimes only within centimeters per year. This applies especially to fragments of incipient foredunes that are densely overgrown with marram grass.

Acknowledgments Thanks are extended to the staff of Słowiński National Park for their kind attitude toward this investigation, Adam Tomaszewski and Paweł Kusideł for UAV operation and service, and Władysław Pawłów for technical support during the field work.

Funding Information The field work, including beach-foredune profiling and the determination of marram grass density, was supported by the Polish National Science Centre (project nos. 2012/05/B/ST10/00680 and 2016/23/B/ST10/01700). The operation of the UAV was partly supported by Słowiński National Park.

\section{Appendix. Results of the Kruskal-Wallis and multiple comparison post hoc tests (in cases where $p<0.05$ for $\mathrm{K}-\mathrm{W}$ tests)}

\begin{tabular}{|c|c|c|c|c|c|c|c|}
\hline \multicolumn{8}{|c|}{ Influence of slope inclination on absolute differences in altitude for all land cover classes combined } \\
\hline \multirow[t]{2}{*}{ Dependent variable: Abs_diff } & \multicolumn{7}{|c|}{ Kruskal-Wallis test: $\mathrm{H}(6, N=1289)=98.47503, p=0.0000$} \\
\hline & $\begin{array}{l}0^{\circ} \\
R=504.18\end{array}$ & $\begin{array}{l}5^{\circ} \\
R=614.46\end{array}$ & $\begin{array}{l}10^{\circ} \\
R=678.38\end{array}$ & $\begin{array}{l}15^{\mathrm{o}} \\
R=739.03\end{array}$ & $\begin{array}{l}20^{\circ} \\
R=757.96\end{array}$ & $\begin{array}{l}25^{\circ} \\
R=769.69\end{array}$ & $\begin{array}{l}30^{\circ} \\
R=817.66\end{array}$ \\
\hline \multicolumn{2}{|l|}{$0^{\circ}$} & 0.004445 & 0.000001 & 0.000000 & 0.000000 & 0.000000 & 0.000000 \\
\hline $5^{\mathrm{o}}$ & \multicolumn{2}{|l|}{0.004445} & 1.000000 & 0.024715 & 0.007866 & 0.003444 & 0.005591 \\
\hline $10^{\circ}$ & 0.000001 & 1.000000 & & 1.000000 & 1.000000 & 0.679872 & 0.299561 \\
\hline $15^{\mathrm{o}}$ & 0.000000 & 0.024715 & 1.000000 & & 1.000000 & 1.000000 & 1.000000 \\
\hline $20^{\circ}$ & 0.000000 & 0.007866 & 1.000000 & 1.000000 & & 1.000000 & 1.000000 \\
\hline $25^{\circ}$ & 0.000000 & 0.003444 & 0.679872 & 1.000000 & 1.000000 & & 1.000000 \\
\hline $30^{\circ}$ & 0.000000 & 0.005591 & 0.299561 & 1.000000 & 1.000000 & 1.000000 & \\
\hline \multicolumn{8}{|c|}{ Influence of slope curvature on absolute differences in altitude for all land cover classes combined } \\
\hline \multirow[t]{2}{*}{ Dependent variable: Abs_diff } & \multicolumn{7}{|c|}{ Kruskal-Wallis test: $H(6, N=1253)=25.80821, p=0.0002$} \\
\hline & $\begin{array}{l}-0.35 \\
R=895.35\end{array}$ & $\begin{array}{l}-0.25 \\
R=716.68\end{array}$ & $\begin{array}{l}-0.15 \\
R=666.98\end{array}$ & $\begin{array}{l}-0.05 \\
R=622.49\end{array}$ & $\begin{array}{l}0.05 \\
R=573.58\end{array}$ & $\begin{array}{l}0.15 \\
R=571.10\end{array}$ & $\begin{array}{l}0.25 \\
R=616.41\end{array}$ \\
\hline-0.35 & & 1.000000 & 0.133810 & 0.019634 & 0.002514 & 0.009847 & 0.408492 \\
\hline-0.25 & 1.000000 & & 1.000000 & 1.000000 & 0.150227 & 0.601913 & 1.000000 \\
\hline-0.15 & 0.133810 & 1.000000 & & 1.000000 & 0.041431 & 1.000000 & 1.000000 \\
\hline-0.05 & 0.019634 & 1.000000 & 1.000000 & & 1.000000 & 1.000000 & 1.000000 \\
\hline 0.05 & 0.002514 & 0.150227 & 0.041431 & 1.000000 & & 1.000000 & 1.000000 \\
\hline 0.15 & 0.009847 & 0.601913 & 1.000000 & 1.000000 & 1.000000 & & 1.000000 \\
\hline 0.25 & 0.408492 & 1.000000 & 1.000000 & 1.000000 & 1.000000 & 1.000000 & \\
\hline
\end{tabular}

Influence of slope inclination on absolute differences in altitude for land cover class 1 (no marram grass)

Kruskal-Wallis test: $H(5, N=356)=4.561568, p=0.4717$

Influence of slope curvature on absolute differences in altitude for land cover class 1 (no marram grass)

Kruskal-Wallis test: $H(6, N=426)=12.29862, p=0.0556$

Influence of slope inclination on absolute differences in altitude for land cover class 2 (marram grass covering up to $20 \%$ of the dune area)

Dependent variable: Abs_diff Kruskal-Wallis test: $(6, N=730)=41.30848, p=0.0000$

$\begin{array}{llllllll} & 0^{\circ} & 5^{\circ} & 10^{\circ} & 15^{\circ} & 20^{\circ} & 25^{\circ} & 30^{\circ} \\ & R=301.65 & R=325.99 & R=329.66 & R=390.81 & R=423.30 & R=410.12 & R=476.87 \\ 0^{\circ} & & 1.000000 & 1.000000 & 0.072364 & 0.002400 & 0.014733 & 0.000392 \\ 5^{\circ} & & & 1.000000 & 0.271891 & 0.007658 & 0.052897 & 0.001364\end{array}$


(continued)

\begin{tabular}{|c|c|c|c|c|c|c|c|}
\hline$\overline{10^{\circ}}$ & 1.000000 & 1.000000 & & 0.410908 & 0.013308 & 0.083902 & 0.002114 \\
\hline $15^{\circ}$ & 0.072364 & 0.271891 & 0.410908 & & 1.000000 & 1.000000 & 0.587826 \\
\hline $20^{\circ}$ & 0.002400 & 0.007658 & 0.013308 & 1.000000 & & 1.000000 & 1.000000 \\
\hline $25^{\circ}$ & 0.014733 & 0.052897 & 0.083902 & 1.000000 & 1.000000 & & 1.000000 \\
\hline $30^{\circ}$ & 0.000392 & 0.001364 & 0.002114 & 0.587826 & 1.000000 & 1.000000 & \\
\hline
\end{tabular}

Influence of slope curvature on absolute differences in altitude for land cover class 2 (marram grass covering up to $20 \%$ of the dune area)

Dependent variable: Abs_diff $\quad$ Kruskal-Wallis test: $H(6, N=827)=18.35745, p=0.0054$

$\begin{array}{llllllll} & -0.35 & -0.25 & -0.15 & -0.05 & 0.05 & 0.15 & 0.25 \\ -0.35 & R=593.94 & R=471.55 & R=436.08 & R=410.59 & R=387.23 & R=370.89 & R=354.00 \\ -0.25 & & 1.000000 & 0.191540 & 0.042540 & 0.013099 & 0.019089 & 0.113055 \\ -0.15 & 1.000000 & & 1.000000 & 1.000000 & 1.000000 & 1.000000 & 1.000000 \\ -0.05 & 0.191540 & 1.000000 & & 1.000000 & 0.978467 & 1.000000 & 1.000000 \\ 0.05 & 0.042540 & 1.000000 & 1.000000 & & 1.000000 & 1.000000 & 1.000000 \\ 0.15 & 0.013099 & 1.000000 & 0.978467 & 1.000000 & & 1.000000 \\ 0.25 & 0.019089 & 1.000000 & 1.000000 & 1.000000 & 1.000000 & 1.000000 \\ & 0.113055 & 1.000000 & 1.000000 & 1.000000 & 1.000000 & 1.000000\end{array}$

Influence of slope inclination on absolute differences in altitude for land cover class 3 (marram grass covering over $20 \%$ of the dune area) Kruskal-Wallis test: $H(6, N=203)=6.988584, p=0.3219$

Influence of slope curvature on absolute differences in altitude for land cover class 3 (marram grass covering over 20\% of the dune area)

Dependent variable: Abs_diff Kruskal-Wallis test: $H(6, N=221)=17.85180, p=0.0066$

$\begin{array}{llllllll} & -0.35 & -0.25 & -0.15 & -0.05 & 0.05 & 0.15 & 0.25 \\ -0.35 & R=96.950 & R=130.59 & R=89.071 & R=106.13 & R=99.972 & R=132.48 & R=158.25 \\ -0.25 & & 1.000000 & 1.000000 & 1.000000 & 1.000000 & 1.000000 & 0.528248 \\ -0.15 & 1.000000 & & 0.441910 & 1.000000 & 1.000000 & 1.000000 & 1.000000 \\ -0.05 & 1.000000 & 0.441910 & & 1.000000 & 1.000000 & 0.205231 & 0.036008 \\ 0.05 & 1.000000 & 1.000000 & 1.000000 & & 1.000000 & 1.000000 & 0.200719 \\ 0.15 & 1.000000 & 1.000000 & 1.000000 & 1.000000 & & 0.536678 & 0.090134 \\ 0.25 & 1.000000 & 1.000000 & 0.205231 & 1.000000 & 0.536678 & \\ & 0.528248 & .000000 & 0.036008 & 0.200719 & 0.090134 & 1.000000 & \end{array}$

Open Access This article is licensed under a Creative Commons Attribution 4.0 International License, which permits use, sharing, adaptation, distribution and reproduction in any medium or format, as long as you give appropriate credit to the original author(s) and the source, provide a link to the Creative Commons licence, and indicate if changes were made. The images or other third party material in this article are included in the article's Creative Commons licence, unless indicated otherwise in a credit line to the material. If material is not included in the article's Creative Commons licence and your intended use is not permitted by statutory regulation or exceeds the permitted use, you will need to obtain permission directly from the copyright holder. To view a copy of this licence, visit http://creativecommons.org/licenses/by/4.0/.

\section{References}

Angell, P. 2018. Desert drones. Land Journal Apr: pp. 26 ProQuest Central; ProQuest One Academic. ISSN 17549094.

Bater, C.W., and N.C. Coops. 2009. Evaluating error associated with LIDAR-derived DEM interpolation. Computers and Geosciences 35 (2): 289-300. https://doi.org/10.1016/j.cageo.2008.09.001.

Bobertz, B., C. Kuhrts, J. Harff, W. Fennel, T. Seifert, and B. Bohling. 2005. Sediment properties in the western Baltic Sea for use in sediment transport modelling. Journal of Coastal Research 21 (3): 588-597. https://doi.org/10.2112/04-705A.1.

Borówka, R.K. 1990. The Holocene development and present morphology of the Łeba dunes, Baltic coast of Poland. In Coastal dunes -
Forms and processes, ed. K.F. Nordstrom, N.P. Psuty, and B. Carter, 289-313. Chichester: Wiley.

Chandler, B.M.P., D.J.A. Evans, D.H. Roberts, M. Ewertowski, and A.I. Clayton. 2016. Glacial geomorphology of the Skálafellsjökull foreland, Iceland: A case study of 'annual' moraines. Journal of Maps 12 (5): 904-916. https://doi.org/ 10.1080/17445647.2015.1096216.

Conrad, O., B. Bechtel, M. Bock, H. Dietrich, E. Fischer, L. Gerlitz, J. Wehberg, V. Wichmann, and J. Böhner. 2015. System for automated geoscientific analyses (SAGA) v. 2.1.4. Geoscientific Model Development 8 (7): 1991-2007. https://doi.org/10.5194/gmd-81991-2015.

Coveney, S., and A.S. Fotheringham. 2011. The impact of DEM data source on prediction of flooding and erosion risk due to sea-level rise. International Journal of Geographical Information Science 25 (7): 1191-1211. https://doi.org/10.1080/13658816.2010.545064.

d'Oleire-Oltmanns, S., I. Marzolff, K.D. Peter, and J.B. Ries. 2012. Unmanned aerial vehicle (UAV) for monitoring soil erosion in Morocco. Remote Sensing 4 (11): 3390-3416. https://doi.org/10. 3390/rs4113390.

Dąbski, M., A. Zmarz, P. Pabjanek, M. Korczak-Abshire, I. Karsznia, and K. Chwedorzewska. 2017. UAV-based detection and spatial analyses of periglacial landforms on Demay Point (King George Island, South Shetland Islands, Antarctica). Geomorphology 290: 29-38. https://doi.org/10.1016/j.geomorph.2017.03.033.

Darke, I.B., I.J. Walker, and P.A. Hesp. 2016. Beach-dune sediment budgets and dune morphodynamics following coastal dune restoration, Wickaninnish Dunes, Canada. Earth Surface Processes and Landforms 41 (10): 1370-1385. https://doi.org/10.1002/esp.3910. 
de Haas, T., D. Ventra, P.E. Carbonneau, and M.G. Kleinhans. 2014. Debris-flow dominance of alluvial fans masked by runoff reworking and weathering. Geomorphology 217: 165-181. https://doi.org/10. 1016/j.geomorph.2014.04.028.

Delgado-Fernandez, I. 2011. Meso-scale modelling of aeolian sediment input to coastal dunes. Geomorphology 130 (3-4): 230-243. https:// doi.org/10.1016/j.geomorph.2011.04.001.

DJI. 2016. Phantom 4 disclaimer and safety guidelines, V1.2; DJI: Shenzhen, China.

Erdogan, S. 2010. Modelling the spatial distribution of DEM error with geographically weighted regression: An experimental study. Computers and Geosciences 36 (1): 34-43. https://doi.org/10. 1016/j.cageo.2009.06.005.

ESRI. 2018. ArcGIS Desktop: Release 10.5. Environmental Systems Research Institute, Redlands CA.

Fabbri, S., B.M.S. Giambastiani, F. Sistilli, F. Scarelli, and G. Gabbianelli. 2017. Geomorphological analysis and classification of foredune ridges based on terrestrial laser scanning (TLS) technology. Geomorphology 295: 436-451. https://doi.org/10.1016/j. geomorph.2017.08.003.

Flener, C., E. Lotsari, P. Alho, and J. Käyhkö. 2012. Comparison of empirical and theoretical remote sensing based bathymetry models in river environments. River Research and Applications 28 (1): 118133. https://doi.org/10.1002/rra.1441.

Goetzendorf-Grabowski, T., and M. Rodzewicz. 2016. Design of UAV for photogrammetric mission in Antarctic area. Journal of Aerospace Engineering. 231 (9): 1660-1675. https://doi.org/10. $1177 / 0954410016656881$.

Goodchild, M.F. 1995. Attribute accuracy. In Elements of spatial data quality, ed. S.C. Guptill and J.L. Morrisson, 59-79. Oxford: Elsevier.

Grellier, S., J. Kemp, J.J. Janeau, N. Florsch, D. Ward, S. Barot, P. Podwojewski, S. Lorentz, and C. Valentin. 2012. The indirect impact of encroaching trees on gully extension: A 64 year study in a sub-humid grassland of South Africa. Catena 98: 110-119. https:// doi.org/10.1016/j.catena.2012.07.002.

Hengl, T. 2006. Finding the right pixel size. Computers and Geosciences 32 (9): 1283-1298. https://doi.org/10.1016/j.cageo.2005.11.008.

Hengl, T., and I.S. Evans. 2009. Mathematical and digital models of the land surface. In Developments in soil science, volume 33: Geomorphometry: Concepts, software, applications, ed. T. Hengl and H.I. Reuter, 31-63. Amsterdam: Elsevier.

Hodgson, M.E., and P. Bresnahan. 2004. Accuracy of airborne Lidarderived elevation: Empirical assessment and error budget. Photogrammetric Engineering and Remote Sensing 70: 331-339. https://doi.org/10.14358/PERS.70.3.331.

Kasprzak, M., K. Jancewic, and A. Michniewicz. 2017. UAV and SfM in detailed geomorphological mapping of granite tors: An example of Starościńskie Skały (Sudetes, SW Poland). Pure and Applied Geophysics 175 (9): 3193-3207. https://doi.org/10.1007/s00024017-1730-8.

Keijsers, J.G.S., A. Poortinga, M. Riksen, and J. Maroulis. 2014. Spatiotemporal variability in accretion and erosion of coastal foredunes in the Netherlands: Regional climate and local topography. PLoS One 9 (3): e91115. https://doi.org/10.1371/journal.pone.0091115.

Kienzle, S. 2004. The effect of DEM raster resolution on first order, second order and compound terrain derivatives. Transactions in GIS 8 (1): 83-112. https://doi.org/10.1111/j.1467-9671.2004. 00169.x.

Laporte-Fauret, Q., V. Marieu, B. Castelle, R. Michalet, S. Bujan, and D. Rosebery. 2019. Low-cost UAV for high-resolution and large-scale coastal dune change monitoring using photogrammetry. Journal of Marine Science and Engineering 7 (63). https://doi.org/10.3390/ jmse7030063.

Le Mauff, B., M. Juigner, A. Ba, M. Robin, P. Launeau, and P. Fattal. 2018. Coastal monitoring solutions of the geomorphological response of beach-dune systems using multi-temporal LiDAR datasets (Vendée coast, France). Geomorphology 304: 121-140. https://doi.org/10.1016/j.geomorph.2017.12.037.

Leon, J.X., G.B.M. Heuvelink, and S.R. Phinn. 2014. Incorporating DEM uncertainty in coastal inundation mapping. PLoS One 9 (9): e108727. https://doi.org/10.1371/journal.pone.0108727.

Liu, X. 2008. Airborne LiDAR for DEM generation: Some critical issues. Progress in Physical Geography 32 (1): 31-49. https://doi.org/10. 1177/0309133308089496.

Mancini, F., M. Dubbini, M. Gattelli, F. Stecchi, S. Fabbri, and G. Gabbianelli. 2013. Using unnamed aerial vehicles (UAV) for highresolution reconstruction of topography: The structure from motion approach on coastal environments. Remote Sensing 5 (12): 6880 6898. https://doi.org/10.3390/rs5126880.

Musick, H.B., S.M. Trujillo, and C.R. Truman. 1996. Wind-tunnel modelling of the influence of vegetation structure on saltation threshold. Earth Surface Processes and Landforms 21 (7): 589-605.

Nelson, A., H.I. Reuter, and P. Gessler. 2009. DEM production methods and sources. In Developments in soil science, volume 33: Geomorphometry: Concepts, software, applications, ed. T. Hengl and H.I. Reuter, 65-85. Amsterdam: Elsevier.

Niethammer, U., M.R. James, S. Rothmund, J. Travelletti, and M. Joswig. 2012. UAV-based remote sensing of the Super-Sauze landslide: Evaluation and results. Engineering Geology 128: 2-11. https://doi.org/10.1016/j.enggeo.2011.03.012.

Nolet, C., M. van Puijenbroek, J. Suomalainen, J. Limpens, and M. Riksen. 2018. UAV-imaging to model growth response of marram grass to sand burial: Implications for coastal dune development. Aeolian Research 31: 50-61. https://doi.org/10.1016/j.aeolia.2017. 08.006 .

Oksanen, J., and T. Sarjakoski. 2006. Uncovering the statistical and spatial characteristics of fine toposcale DEM error. International Journal of Geographical Information Science 20 (4): 345-369. https://doi.org/10.1080/13658810500433891.

Rader, A.M., A.J. Pickart, I.J. Walker, P.A. Hesp, and B.O. Bauer. 2018. Foredune morphodynamics and sediment budgets at seasonal to decadal scales: Humboldt Bay National Wildlife Refuge, California, USA. Geomorphology 318: 69-87. https://doi.org/10. 1016/j.geomorph.2018.06.003.

Rahman, A.F., J.A. Gamon, D.A. Sims, and M. Schmidts. 2003. Optimum pixel size for hyperspectral studies of ecosystem function in southern California chaparral and grassland. Remote Sensing of Environment 84 (2): 192-207.

Rodzewicz, M., D. Głowacki, and J. Hajduk. 2017. Some dynamic aspects of photogrammetry missions performed by "PW-ZOOM" The UAV of Warsaw University of Technology. Archive of Mechanical Engineering 64 (1): 37-55. https://doi.org/10.1515/ meceng-2017-0003.

Rotnicka, J. 2011. Factors controlling the development of foredunes along the Leba Barrier on the south Baltic coast of Poland. Journal of Coastal Research SI 64: 308-313.

Rotnicka, J. 2013a. Transport eoliczny na plaży morza bezplywewgo: natężenie, uwarunkowania $i$ wpływ na tworzenie wydm przednich (na przykładzie bariery łebskiej). Poznań: Bogucki Wydawnictwo Naukowe. (In Polish, with English summary).

Rotnicka, J. 2013b. Aeolian vertical mass flux profiles above dry and moist sandy beach surfaces. Geomorphology 187: 27-37. https:// doi.org/10.1016/j.geomorph.2012.12.032.

Rotnicka, J., and M. Dłużewski. 2019. A method to derive long-term coastal wind data from distant weather station to improve aeolian sand transport rate prediction. Aeolian Research 38: 24-38. https:// doi.org/10.1016/j.aeolia.2019.03.002.

Rotnicki, K. 1995. An outline of geomorphology and main problems of the Upper Quaternary of the Gardno-Eeba coastal plain. Journal of Coastal Research SI 22: 213-219. 
Rotnicki, K., and R.K. Borówka. 1995. Evidence of the Litorina Sea at Kluki, Gardno-Łeba coastal plain. Journal of Coastal Research SI 22: 231-235.

Sappington, J.M., K.M. Longshore, and D.B. Thompson. 2007. Quantifying landscape ruggedness for animal habitat analysis: A case study using bighorn sheep in the Mojave Desert. Journal of Wildlife Management 71 (5): 1419-1426.

Scarelli, F.M., F. Sistilli, S. Fabbri, L. Cantelli, E.G. Barboza, and G. Gabbianelli. 2017. Seasonal dune and beach monitoring using photogrammetry from UAV surveys to apply in the ICZM on the Ravenna coast (Emilia-Romagna, Italy). Remote Sensing Applications: Society and Environment 7: 27-39.

Schmid, K.A., B.C. Hadley, and N. Wijekoon. 2011. Vertical accuracy and use of topographic LIDAR data in coastal marshes. Journal of Coastal Research 27: 116-132.

Shortridge, A.M. 2001. Characterizing uncertainty in digital elevation models. In Spatial uncertainty for ecology: Implications for remote sensing and GIS applications, ed. C. Hunsaker, M. Goodchild, M. Friedl, and T.J. Case, 238-257. New York: Springer.

Silva, O.L., F.H.R. Bezerra, R.P. Maia, and C.L. Cazarin. 2017. Karst landforms revealed at various scales using LiDAR and UAV in semi-arid Brazil: Consideration on karstification processes and methodological constraints. Geomorphology 295: 611-630. https:// doi.org/10.1016/j.geomorph.2017.07.025.

Su, J., and E. Bork. 2006. Influence of vegetation, slope, and LiDAR sampling angle on DEM accuracy. Photogrammetric Engineering and Remote Sensing 72: 1265-1274. https://doi.org/10.14358/ PERS.72.11.1265.

Taroli, P. 2014. High-resolution topography for understanding earth surface processes: Opportunities and challenges. Geomorphology 216: 295-312. https://doi.org/10.1016/j/geomorph.2014.03.008.

Taroli, P., G. Sofia, and G.D. Fontana. 2012. Geomorfic features extraction from high-resolution topography: Landslide crowns and bank erosion. Natural Hazards 61 (1): 65-83. https://doi.org/10.1007/ s11069-010-9695-2.
Vespremeanu-Store, A., and L. Preoteasa. 2007. Beach-dune interactions on the dry-temperate Danube delta coast. Geomorphology 86 (3-4): 267-282. https://doi.org/10.1016/j.geomorph.2006.09.011.

Wang, S., M. Garcia, P. Bauer-Gottwein, J. Jakobsen, P.J. Zarco-Tejada, F. Bandini, V.S. Paz, and A. Ibrom. 2019. High spatial resolution monitoring land surface energy, water and $\mathrm{CO} 2$ fluxes from an unmanned aerial system. Remote Sensing of Environment 229: 14 31.

Webster, R., and M.A. Oliver. 2007. Geostatistics for environmental scientists. Chichester: Wiley.

Wechsler, S.P., and C.N. Kroll. 2006. Quantifying DEM uncertainty and its effect on topographic parameters. Photogrammetric Engineering and Remote Sensing 72 (9): 1081-1090. https://doi.org/10.14358/ PERS.72.9.1081.

Wheaton, J.M., J. Brasington, S.E. Darby, and D. Sear. 2009. Accounting for uncertainty in DEMs from repeat topographic surveys: Improved sediment budgets. Earth Surface Processes and Landforms 35: 136-156. https://doi.org/10.1002/esp.1886.

Whitehead, K., B.J. Moorman, and C.H. Hugenholtz. 2013. Brief communication: Low-cost, on-demand aerial photogrammetry for glaciological measurement. Cryosphere 7 (6): 1879-1884. https://doi. org/10.5194/tc-7-1879-2013.

Zandbergen, P.A. 2011. Characterizing the error distribution of lidar elevation data for North Carolina. International Journal of Remote Sensing 32 (2): 409-430. https://doi.org/10.1080/ 01431160903474939 .

Zeverbergen, L.W., and C.R. Thorne. 1987. Quantitative analysis of land surface topography. Earth Surface Processes and Landforms 12: 47-56. https://doi.org/10.1002/esp.3290120107.

Zmarz, A., M. Rodzewicz, M. Dą̧ski, I. Karsznic, M. Korczak-Abshire, and K.J. Chwedorzewska. 2018. Application of UAV BVLOS remote sensing data for multi-faceted analysis of Antarctic ecosystem. Remote Sensing of Environment 217: 375-388. https://oi.org/10. 1016/j.rse.2018.08.031. 